\title{
PENYULUHAN ASUPAN GIZI UNTUK MENINGKATKAN STATUS GIZI PADA BALITA DI POSYANDU MELATI RW 09 PANYILEUKAN BANDUNG
}

\author{
Ani Anggriani ${ }^{1}$, Ida Lisni ${ }^{1}$, Ni Nyoman Sri Mas Hartini ${ }^{1}$ \\ ${ }^{1}$ Fakultas Farmasi, Universitas Bhakti Kencana \\ ani.anggriani@bku.ac.id
}

\begin{abstract}
Increasing the nutritional status of children under five in the Posyandu Melati has become the target of the PKK work program to reduce nutrition by up to $20 \%$ according to WHO's stipulations. $P K K$ is a forum for women's organizations with various educational backgrounds. PKK mothers are diverse, namely junior high, high school, tertiary institutions, mostly housewives. The results of the analysis showed that the PKK activities were not yet optimal due to the limited ability and knowledge of PKK mothers. Therefore, a concrete solution is needed in an effort to further enhance the empowerment of PKK mothers. It is hoped that through community service activities, understanding and application will be enhanced in providing information on nutrition intake for infants. So that this training is expected to be able to complete the knowledge of knowledge in various aspects of family life, which can be used to show their existence, in improving the nutritional status of children under five in Posyandu Melati RW 09. Methods of carrying out activities include body weight measurements; Counseling about proper nutrition in infants and things that improve nutritional status; Evaluate the results of activities.
\end{abstract}

Keywords: Counseling, Nutrition, Weight

\begin{abstract}
ABSTRAK
Peningkatan Status gizi pada balita di Posyandu Melati menjadi target program kerja PKK untuk mengurangi gizi bruk hingga 20\% sesuai penetapan WHO. PKK merupakan salah satu wadah organisasi perempuan dengan Latar belakang pendidikan ibu-ibu PKK tersebut beragam yaitu SMP, SMA, perguruan tinggi sebagian besar adalah ibu rumah tangga. Hasil analisis menunjukkan belum optimalnya kegiatan PKK, yang disebabkan karena keterbatasan kemampuan dan keilmuan ibu-ibu PKK. Oleh karena itu diperlukan suatu solusi yang konkret sebagai upaya untuk lebih meningkatkan keberdayaan ibu-ibu PKK tersebut diharapkan dengan kegiatan pengabdian masyarakat ini peningkatan pemahaman dan apliaksi dalam pemberian informasi tentang asupan gizi pada balita. Sehingga pembinaan ini diaharapkan dapat melengkapi wawana pengetahuan dalam berbagai segi kehiduapan kelaurga, yang dapat digunakan untuk menunjukkan eksistensi dirinya, dlam meningkatkan status gizi pada balita di Posyandu melati RW 09. Metode pelaksanaan kegiatan meliputi Pengukuran Berat Badan ; Penyuluhan tentang
\end{abstract}

12 Edukasi Masyarakat Sehat Sejahtera (EMaSS) : Jurnal Pengabdian kepada Masyarakat Volume 2 No.1 Tahun 2020 
asupan gizi yang benar pada balita dan hal-hal yang meningkatkan status gizi; Evaluasi hasil kegiatan.

Kata Kunci : Asupan Gizi, Berat Badan, Penyuluhan.

\section{PENDAHULUAN}

Masalah gizi buruk dan penyakit tidak menular tampaknya bakal tetap menghantui Indonesia pada 2019 mendatang. Catatan Riset Kesehatan Dasar 2018 menunjukkan adanya perbaikan status gizi buruk pada balita di Indonesia. Proporsi status gizi sangat pendek turun dari 37,2 persen (Riskesdas 2013) menjadi 30,8 persen (Riskesdas 2018). Kendati menurun, tapi penurunan yang tercatat dinilai masih kurang signifikan. Organisasi Kesehatan Dunia (WHO) menetapkan batas prevalensi 20 persen untuk gizi buruk.

Pola konsumsi makanan dan minuman masyarakat terutama balita di RW 09 tampaknya perlu dievaluasi, Memiliki anak yang cerdas dan berkompeten pasti merupakan dambaan setiap orang tua. Salah satu hal penting yang harus dilakukan adalah menghindari anak kekurangan gizi. Gizi seimbang merupakan slogan '4 sehat 5 sempurna' hal ini sudah berkembang pada IPTEK Ilmu Pengetahuan dan Teknologi. Dengan mengimplementasikannya pedoman tersebut diyakini bahwa masalah gizi beban ganda dapat teratasi. Hanya saja memberikan gizi seimbang untuk anak 2 -- 5 tahun cukup menjadi masalah dan perlu diperhatikan dalam memberikan nutrisi yang lengkap kepada anak.

Evaluasi terhadap status gizi pada balita di posyandu melati RW 09 belum dilaksanakan secara maksimal segingga target program yang akan dicapai dalam meningkatkan status gizi tidak lebih dari 20\% tidak diketahui secara pasti oleh mitra ibu-ibu PKK Posyandu Melati RW09. Hal ini dibutuhkan pelatihan atau pendampingan dalam melakukan penyuluhan tentang asupan gizi yang benar untuk balita.

\section{METODE}

Metode pelaksanaan kegiatan yang akan dilakukan adalah sebagai berikut :

1. Penyuluhan :

Materi penyuluhan tentang asupan gizi yang benar untuk balita.

2. Pengukuran Berat Badan sebelum pemberian informasi dan sesudah informasi

13 | Edukasi Masyarakat Sehat Sejahtera (EMaSS) : Jurnal Pengabdian kepada Masyarakat Volume 2 No.1 Tahun 2020 
3. Prosedur kegiatan :

a. Koordinasi dengan mitra, terkait dengan penyusunan jadwal kegiatan;

b. Pengukuran Berat Badan ;

c. Pemberian kuesioner sebelum diberikan informasi dan sesudah informasi

d. Penyuluhan tentang asupan gizi yang benar pada balita dan hal-hal yang meningkatkan status gizi 5) Evaluasi hasil kegiatan.

4. Partisipasi Mitra :

Partisipasi mitra dalam pelaksanaan kegiatan ini adalah partisipasi aktif, dari mulai perencanaan kegiatan, penyusunan jadwal penyuluhan. Partisipasi mitra akan dievaluasi selama dan setelah pelaksanaan kegiatan penyuluhan.

\section{HASIL DAN PEMBAHASAN}

Penyuluhan tentang asupan gizi pada balita dilakukan oleh ibu-ibu PKK RW 09, sebelum dan sesudah penyuluhan di ukur berat badan pada balita, berikut data berat badan balita di RW 09.

Tabel 1. Pengukuran Berat Badan Balita RW 09 Panyileukan Bandung

\begin{tabular}{c|c|c}
\hline Kenaikan Berat Badan $(\mathrm{Kg})$ & Jumlah Balita & Persentase (\%) \\
\hline Tetap & 8 & 32 \\
\hline Naik 0,1 $-0,5$ & 9 & 36 \\
\hline Naik 0,6-1 & 5 & 20 \\
\hline Naik >1 & 3 & 12 \\
\hline Total & 25 & 100 \\
\hline
\end{tabular}

Pada Tabel 1 menunjukkan bahwa terdapat kenaikan berat badan sekitar 0,1 -0,5 kg pada balita sebanyak 36\%, kenaikan berat badan 0,6 -1 kg pada balita sebanyak 20\%, dan kenaikan diatas $1 \mathrm{~kg}$ pada balita sebanyak 12\%, dengan total sebesar $68 \%$ mengalami kenaikan berat badan

14 | Edukasi Masyarakat Sehat Sejahtera (EMaSS) : Jurnal Pengabdian kepada Masyarakat Volume 2 No.1 Tahun 2020 
setelah dilakukan penyuluhan tentang asupan gizi pada balita di posyandu melati RW 09 Panyileukan Bandung.

Hasil penyuluhan tentang asupan gizi yang benar kepada orang tua atau wali balita dilakukan melalui pemberian kuesioner 10 soal tentang asupan gizi seimbnag pada untuk anak 25 tahun, kemudian dianalisis dengan tingkat pengetahuan berdasarkan pustaka Arikunto (2013: 387) pengukuran tingkat pengetahuan dapat dibagi menjadi 3 macam kategori, yaitu :

1. Kategori baik : $>75 \%$

2. Kategori cukup : $60-75 \%$

3. Kategori Kurang $:<60 \%$

Tabel 2 . Tingkat Pengetahuan tentang Asupan Gizi pada Balita

\begin{tabular}{c|c|c|c|c}
\hline \multirow{2}{*}{ Pengetahuan Orang Tua Balita } & \multicolumn{2}{|c|}{ Sebelum Penyuluhan } & \multicolumn{2}{c}{ Sesudah Penyuluhan } \\
\cline { 2 - 5 } & Jumlah Responden & $\%$ & Jumlah Responden & $\%$ \\
\hline Kurang & 20 & 80 & 0 & 0 \\
\hline Cukup & 3 & 12 & 1 & 4 \\
\hline Baik & 2 & 8 & 24 & 96 \\
\hline Total & 25 & 100 & 25 & 100 \\
\hline Rata-Rata & $42,7 \%$ & $98,6 \%$ & \\
\hline
\end{tabular}

Hasil analisis kuesioner pengetahuan responden dari balita RW 09 pada tabel 2 menunjukkan bahwa rata-rata hasil pengetahuan sebelum penyuluhan dari pengukuran tingkat pengetahuan berdasarkan Arikunto (2013) menunjukkan hasil sebesar 42,7\% dan termasuk kategori kurang. Setelah diberikan penyuluhan meningkat menjadi 98,6\% dengan kategori baik, Hal ini menunjukkan adanya hubungan yang signifikan antara pemberian penyuluhan tentang asupan gizi yang benar pada balita dengan hasil berat badan balita di RW 09 Panyileukan Bandung yaitu sebesar 68\% . Dari hasil kuesioner yang diambil dari Kementrian Kesehatan Direktorat Bina Gizi Masyarakat tentang asupan gizi seimbang untuk anak 2-5 tahun menunjukkan orang tua balita di RW 09 sudah memberikan makanan kepada balita beraneka ragam, melakukan pola hidup yang sehat, memantau berat badan balita setiap bulan, mengkonsumsi minum air putih untuk asupan yang seimbang sebanyak 1,6 liter atau 8 gelas 
kemudian menghindari makanan olahan industri, mengetahui makanan yang mengakibatkan pertumbuhan yang tidak baik pada balita sehingga harus diperhatikan jumlah makanan yang mengandung garam, gula dan lemak. Orang tua balita di RW 09 sudah mengetahui makanan pokok yang diberikan adalah 3-8 porsi, sayuran yang diberikan kepada balita 3-5 porsi dan buahbuahan sebanyak 2-3 porsi.

\section{SIMPULAN}

Berdasarkan hasil pelaksanaan kegiatan pengabdian, dapat disimpulkan menunjukkan adanya hubungan yang signifikan antara pemberian penyuluhan tentang asupan gizi yang benar pada balita dengan peningkatan status gizi pada balita dilihat dari hasil kenaikan berat badan balita RW 09 Panyileukan Bandung. Rekomendasi di harapkan dilakukan pengabdian masyarakat yang sama dengan penyuluhan yang kontinue setiap bulan sehingga peningkatan status gizi akan senantiasa meningkat.

\section{DAFTAR PUSTAKA}

Arikunto, S. (2013). Prosedur Penelitian: Suatu Pendekatan Praktik. Jakarta: Rineka Cipta.

Kementrian Kesehatan. (2018). Laporan Hasil Riset Kesehatan Dasar . Jakarta : Badan Penelitian dan Pengembangan Kesehatan. Dilihat tanggal 22 Juni 2019 <http://labdata.litbang.depkes.go.id/riset-badan-litbangkes/ >

Kementrian Kesehatan Republik Indonesia. (2018). Pembinaan Bina Gizi Masyarakat. Jakarta : $\begin{array}{llllll}\text { Direktorat Bina Gizi Masyarakat. Dilihat tanggal } 09 \text { Juli } 2019 & \end{array}$ <http://www.depkes.go.id >

Kementrian Kesehatan Republik Indonesia.(2017). Sistem Informasi Gizi Terpadu tentang Asupan Gizi Seimbang untuk Anak 2-5 Tahun . Jakarta : Direktorat Gizi Masyarakat. Dilihat tanggal 12 Agustus 2019 < http://www.gizi.depkes.go.id/sigizi/ > 